\title{
心臟インターベンション時の 皮虐入射線量実測による多施設線量評価
}

加藤 守 $^{1,2}$ 千田浩一 ${ }^{2}$ 盛武 敬 ${ }^{3}$ 小口靖弘 ${ }^{4}$ 加賀勇治 ${ }^{5}$ 坂本 肇 塚本篤子 ${ }^{7}$ 川内 覚 ${ }^{8}$ 松本一真 ${ }^{9}$ 松村光章 ${ }^{10}$ 大阪 肇 ${ }^{1}$ 豊嶋英仁 ${ }^{1}$

1秋田県立脳血管研究センター放射線科診療部

2 東北大学大学院医学系研究科

${ }^{7}$ NTT 東日本関東病院放射線部 8 虎の門病院放射線部

3 産業医科大学産業生態科学研究所

4 株式会社千代田テクノル大洗研究所

5 仙台厚生病院放射線部

${ }^{6}$ 山梨大学医学部附属病院放射線部
9 兵庫医科大学病院放射線技術部

10 神戸赤十字病院放射線科部

(現 Cardiovascular Research Foundation and

Columbia University Medical Center)

\section{Multicenter Study on Evaluation of the Entrance Skin Dose by a Direct Measurement Method in Cardiac Interventional Procedures}

Mamoru Kato, ${ }^{1,2 *}$ Koichi Chida, ${ }^{2}$ Takashi Moritake, ${ }^{3}$ Yasuhiro Koguchi, ${ }^{4}$ Yuji Kaga, ${ }^{5}$ Hajime Sakamoto, ${ }^{6}$ Atsuko Tsukamoto, ${ }^{7}$ Satoru Kawauchi, ${ }^{8}$ Kazuma Matsumoto, ${ }^{9}$ Mitsuaki Matsumura, ${ }^{10}$

Hajime Oosaka, ${ }^{1}$ and Hideto Toyoshima ${ }^{1}$

${ }^{1}$ Department of Radiology, Research Institute for Brain and Blood Vessels-Akita

${ }^{2}$ Tohoku University Graduate School of Medicine

${ }^{3}$ Institute of Industrial Ecological Sciences, University of Occupational and Environmental Health

${ }^{4}$ Oarai Research Center, Chiyoda Technol Corporation

${ }^{5}$ Department of Radiology, Sendai Kosei Hospital

${ }^{6}$ Department of Radiology, University of Yamanashi Hospital

${ }^{7}$ Department of Radiology, Kanto Medical Center NTT EC

${ }^{8}$ Department of Radiological Technology, Toranomon Hospital

${ }^{9}$ Department of Radiology, Hyogo College of Medicine Hospital

${ }^{10}$ Department of Radiological Technology, Japanese Red Cross Kobe Hospital (Current address: Cardiovascular Research Foundation and Columbia University Medical Center)

Received July 2, 2015; Revision accepted November 16, 2015

Code Nos. 600, 800

\section{Summary}

Deterministic effects have been reported in cardiac interventional procedures. To prevent radiation skin injuries in percutaneous coronary intervention (PCI), it is necessary to measure accurate patient entrance skin dose (ESD) and maximum skin absorbed dose (MSD). We measured the MSD on 62 patients in four facilities by using the Chest-RADIREC ${ }^{\circledR}$ system. The correlation between MSD and fluoroscopic time, dose area product (DAP), and cumulative air kerma (AK) showed good results, with the correlation between MSD and AK being the strongest. The regression lines using MSD as an outcome value $(y)$ and AK as predictor variables $(x)$ was $y=1.18 x\left(R^{2}=0.787\right)$. From the linear regression equation, MSD is estimated to be about 1.18 times that of AK in real time. The Japan diagnostic reference levels (DRLs) 2015 for IVR was established by the use of dose rates using acrylic plates (20$\mathrm{cm}$ thick) at the interventional reference point. Preliminary reference levels proposed by International Atomic Energy Agency (IAEA) were provided using DAP. In this study, AK showed good correlation most of all. Hence we think that Japanese DRLs for IVR should reconsider by clinical patients' exposure dose such as AK.

Key words: patient entrance skin dose (ESD), dosimetry, radio-photoluminescence glass dosimeter (RPLD), diagnostic reference levels (DRLs), percutaneous coronary intervention (PCI)

*Proceeding author 


\section{緒 言}

日本循環器学会の循環器疾患診療実態調査による と, 2013 年の経皮的冠動脈インターベンション (percutaneous coronary intervention: PCI) 施行件数は年間 25 万件を超えている11. 多数の患者が PCIにより quality of life(QOL)の改善を得ている一方, 放射線被 曝による皮虐障害が現在でも報告されている2 4). PCIによる放射線皮膚障害を回避するには，被曝線量 が最大となる皮膚面での被曝線量を実測し管理する必 要があるが，実測方法は確立されていない，特にPCI は照射野の重複や繰り返し行われる症例もあり, 最大 入射皮膚線量とその部位の把握が重要となる ${ }^{5)}$. 現 在, 国際電気標準会議 (International Electrotechnical Commission: IEC) および日本工業規格 (Japanese Industrial Standards: JIS)により，血管撮影装置の被 曝管理を目的として, 面積線量積 (dose-area product: DAP) と積算患者照射基準点線量 (cumulative air kerma: AK) が装置に表示されるシステムとなっている が，いずれも X 線装置のメカニカルな線量值で患者 の最大皮膚線量およびその部位を正確に評価していな い. 最大皮膚線量の把握が不十分な場合，障害の程度 を予測し治療につなげる事が遅れ，更なる重症化を招 く場合も考えられる.

本研究は日本放射線技術学会から支援を受け，研究 調查班として PCI 時の患者被曝線量を実測する方法 を開発し，多施設にて臨床実測デー夕を収集した。実 測した患者最大皮膚線量 (maximum skin dose: MSD) を従来の装置表示被曝管理值である透視時間 (fluoroscopic time: FT), DAP, AK との関係を解析し, 回帰 式から MSD の推測が可能であるかを検討した。

また国際放射線防護委員会 (International Commission on Radiological Protection: ICRP) は 2007 年に診断参考レベル (diagnostic reference levels: DRLs)の構築を提唱した。本邦でも DRLs が発表さ れたが，画像下治療 (interventional radiology: IVR) 時 の DRLs 構築には MSD の実測が必要と考えるが，す べての施設で MSD を実測することは不可能である. 今回収集したデー夕が，国内放射線防護体系へ取り达 む際の基礎的なデータとなるよう解析を行った。

\section{1. 方 法}

\section{1-1 線量素子}

患者皮膚線量の測定には蛍光ガラス線量計 (radiophotoluminescence glass dosimeter: RPLD)を用いた. RPLD はエネルギー依存性により，通常は錫のエネル ギー補償フィルタが付加されている6). しかし錫フィ
ルタはX 線不透過物質で画像上障害院影となるため, エネルギー補償フィルタのない RPLD (GD-302Mㄱ), 千代田テクノル社製)を使用した，GD-302M はプラス チック製のカプセルに入った直径 $1.5 \mathrm{~mm}$, 長さ 12 $\mathrm{mm}$ の銀活性リン酸塩ガラスである。 GD-302M の測 定/読み出しシステムは千代田テクノル社製の校正済 みの Dose Ace FGD-1000 を用いた。

\section{1-2 使用装置}

評価に使用した血管撮影装置は,

・秋田県成人病医療センター：東芝社製 Infinix, 総 ろ過は $0.06 \mathrm{~mm} \mathrm{Ta}+2.6 \mathrm{~mm} \mathrm{Al}$

- 虎の門病院：Philips 社製 Allura, 総ろ過は透視時 が $0.4 \mathrm{~mm} \mathrm{Cu}+4.2 \mathrm{~mm} \mathrm{Al}$, 撮影時が $0.1 \mathrm{~mm}$ $\mathrm{Cu}+4.2 \mathrm{~mm} \mathrm{Al}$

- NTT 東日本関東病院：SIEMENS 社製 Artis，総乃

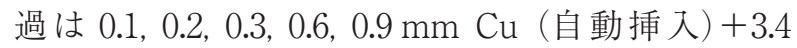
$\mathrm{mm} \mathrm{Al}$

- 仙台厚生病院, 兵庫医科大学病院: 東芝社製 Infinix，総ろ過は $0.5 \mathrm{~mm} \mathrm{Cu}+2.6 \mathrm{~mm} \mathrm{Al}$

である。

全施設の装置で実効エネルギーの測定を行い，GD$302 \mathrm{M}$ の諸特性に関する実験は秋田県成人病医療セン 夕ー, 虎の門病院, NTT 東日本関東病院の装置で行 い, 臨床測定は秋田県成人病医療センター, NTT 東 日本関東病院，仙台厚生病院，兵庫医科大学病院の装 置を用いて行った。

\section{1-3 GD-302M の諸特性について(基礎検討)}

線量および線量率依存性は電離箱線量計と極めてよ い相関があることが知られている。また，GD-302M の長軸方法に関して方向依存性が存在するが, 臨床測 定時の貼付方法を工夫することで方向依存性による影 響は生じない7)

\section{1-3-1 実効エネルギーの測定}

Fig. 1 に示すジオメトリにて, 全施設の装置に対し てアルミニウム半価層測定法を用いて実効エネルギー を測定した，測定はマニュアルスポット撮影にて管電 圧 $70,80,90,100,110,120 \mathrm{kV}$ で行った。なお，実効工 ネルギー測定にあたって, 事前にメーカ保守点検で表 示值と実測值の整合性が担保されていることを確認 した。

\section{1-3-2ＧD-302M のエネルギー依存性}

秋田県成人病医療センター, 虎の門病院, NTT 東 日本関東病院の装置を用いて，GD-302M のエネル ギー依存性を評価した。Fig. 2 に示すように，散乱線 


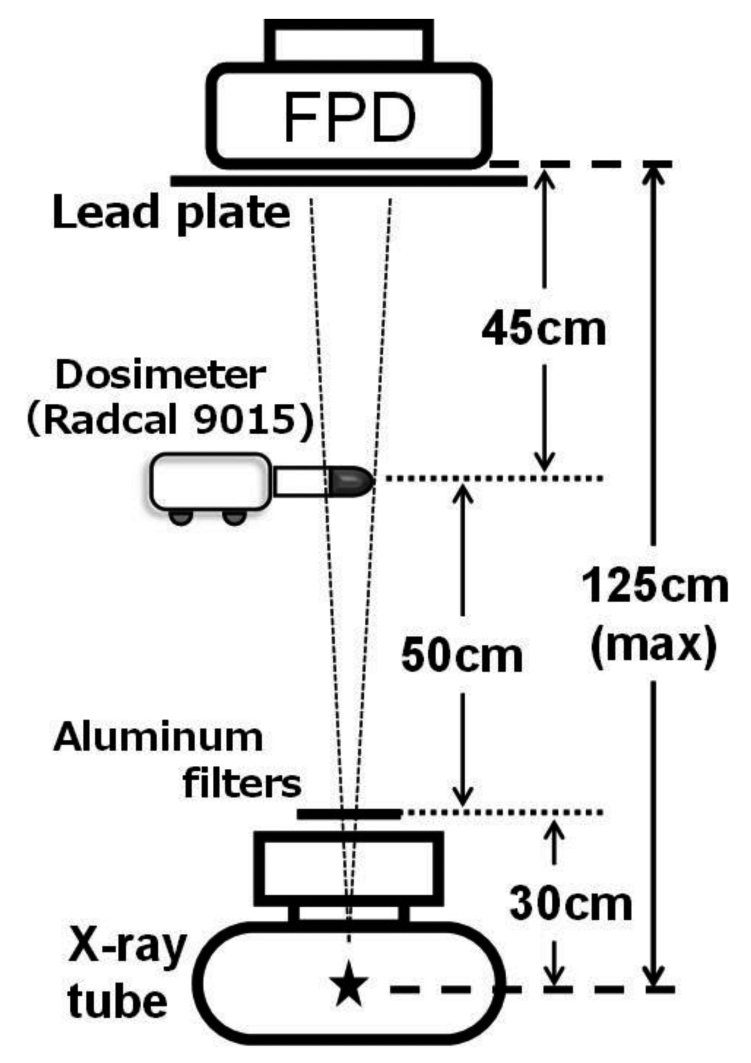

Fig. 1 HVL measurement geometry.

Lead plate was used below the flat panel detector to prevent damage to the detector.

の影響を避けるため $5 \mathrm{~cm}$ の発泡スチロールと $3 \mathrm{~cm}$ のスポンジを利用して, GD-302M と電離箱線量計の 中心が同一平面となるように設置した。そその上で，前 述の管電圧ごとに電離箱線量計の照射線量値 200 $\mu \mathrm{C} / \mathrm{kg}$ を目標に照射した。実際に照射した電離箱線 量計の值を $200 \mu \mathrm{C} / \mathrm{kg}$ で正規化し，GD-302M の読取 值に補正して評価した。

\section{1-3-3ＧD-302M のエネルギー補正係数}

GD-302M のエネルギー補正係数の算出は, 各管電 圧に1-3-2 での測定で得られた電離箱線量計の照射線 量実測值を空気吸収線量に変換し，GD-302M の測定 值で除して算出した。

\section{1-4＼cjkstart臨床時の線量実測方法 (臨床検討)}

臨床時の線量実測には，患者の背面に $2.5 \mathrm{~cm}$ 間隔 でGD-302M を 84 個を配置した専用患者装具(胸部 RADIREC $\left.^{\circledR}\right)$ を開発し使用した ${ }^{8}$ (Fig. 3)。測定は秋田 県成人病医療センター, NTT 東日本関東病院，仙台 厚生病院，兵庫医科大学病院の 4 施設において無作為 に抽出した診断冠動脈造影検査 (coronary angiography: CAG) 19 症例, PCI 43 症例の合計 62 症例を対象 に，皮膚線量分布および最大皮膚線量を実測した。測

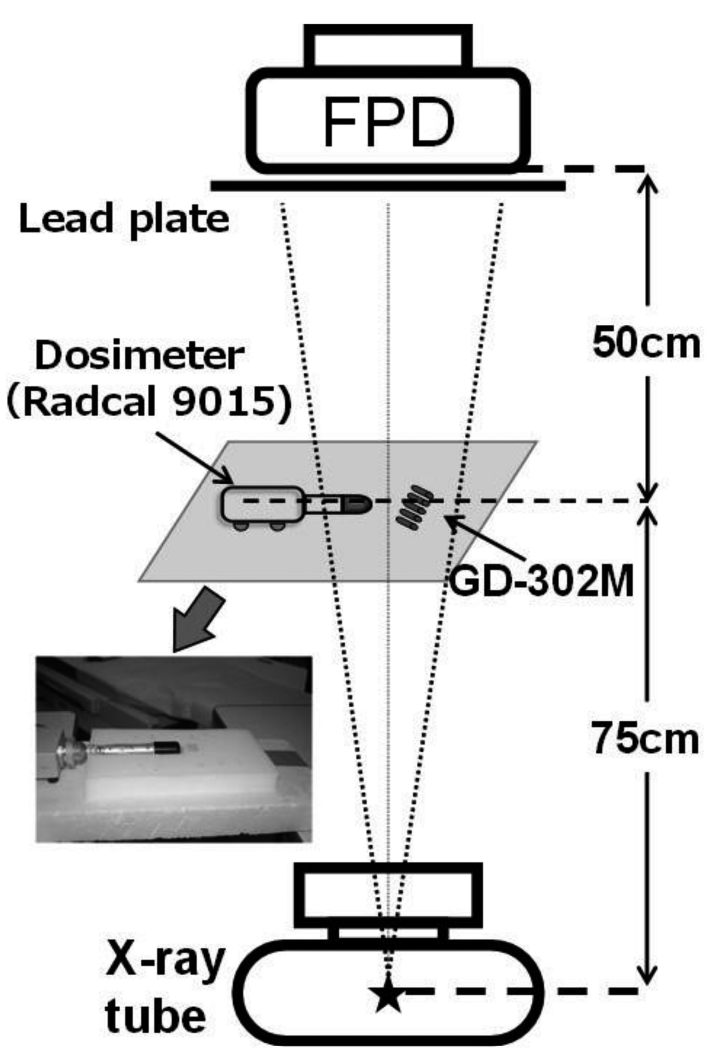

Fig. 2 Effective tube voltage dependence of the GD-302M measurement geometry.

定に当たっては患者背景〔身長，体重 ; 平均值士標準 偏差 (standard deviation: SD)]も調査した。

患者皮膚線量の算出は測定值にエネルギー校正定数 と空気軟部組織吸収線量変換係数を乗じて求めた。臨 床で使用する管電圧が $70 \mathrm{kV}(40 \mathrm{keV})$ から $120 \mathrm{kV}(60$ $\mathrm{keV})$ の範囲で変化するため, 1-3-3 で求められた各管 電圧のエネルギー補正係数の平均值を求め, エネル ギー校正定数として使用した。同様に，空気軟部組織 吸収線量変換係数は S. M. Seltzer and J. H. Hubbell の 光子減弱係数データブック9)より, 各実効エネルギー に対する空気の質量エネルギー吸収係数と軟部組織の 質量エネルギー吸収係数の比を求め, その平均值 1.06 を用いた。

また，フリーの等高線作図ソフト (avese: http://hp. vector.co.jp/authors/VA011972/)を用いて皮膚線量分 布図を作成し，線量分布を視覚評価した。

得られた MSD と従来の被曝管理值である FTや DAP, AK において, CAG 群と PCI 群に有意差があ るかマン・ホイットニーのU U 検定を行った。また, FT, DAP, AK と MSD との相関を解析し, 一次回帰 式により MSD の推定が可能か検討した.

臨床データ収集は, 秋田県成人病医療センター, 

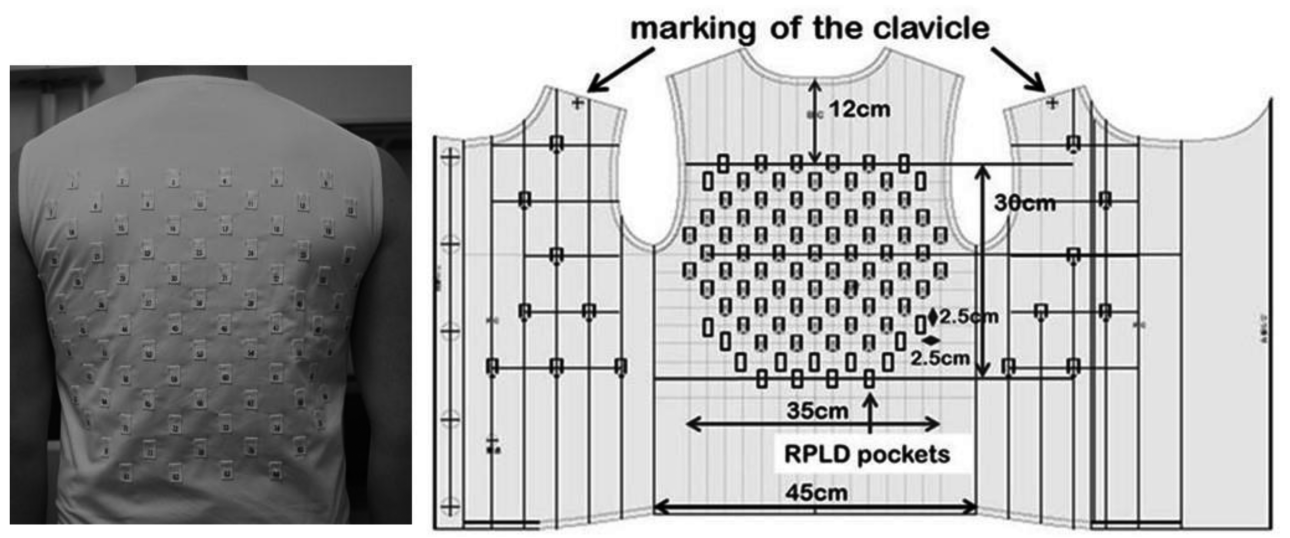

Fig. 3 Chest-RADIREC ${ }^{\circledR}$.

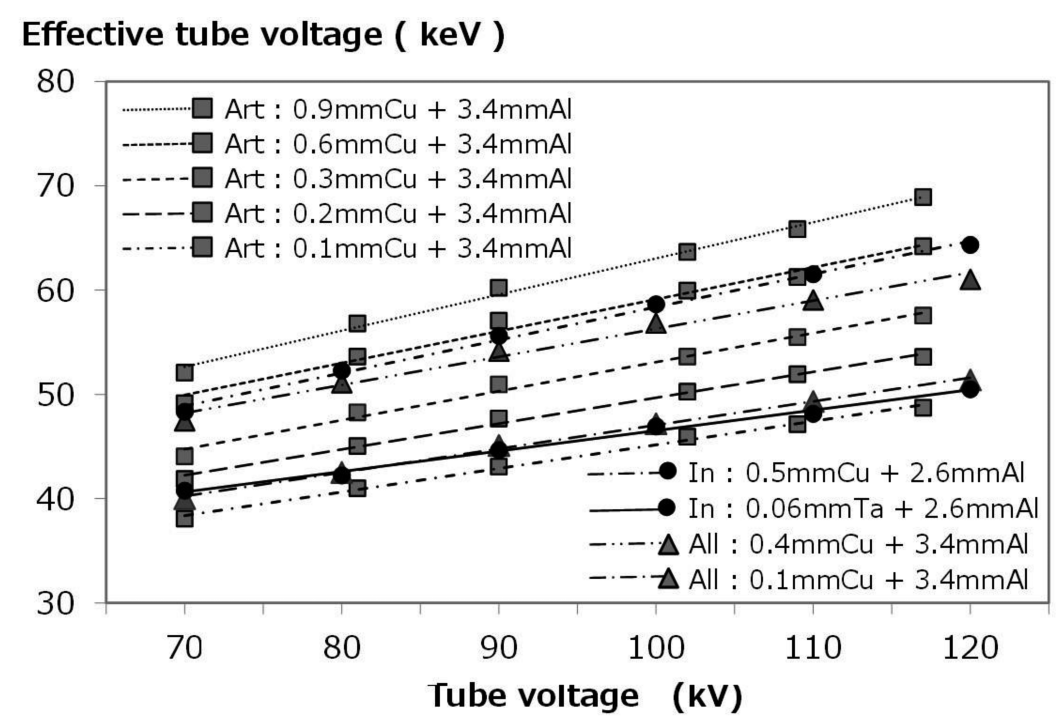

Fig.4 Relationship between effective tube voltage $(\mathrm{keV})$ and tube voltage $(\mathrm{kV})$ SIEMENS Artis: Art, PHILIPS Allura: All. TOSHIBA Infinix: In.

NTT 東日本関東病院, 仙台厚生病院, 兵庫医科大学 病院で行った。各施設で倫理委員会に審査申請し承認 を得，対象となる本人およびその家族に，被曝線量測 定および線量データ解析の重要性を説明し理解を得た うえで自由な意思による同意を得た。

\section{2. 結 果}

\section{2-1 実効エネルギー}

全施設の装置の実効エネルギーを Fig. 4 に示す。総 ろ過の違いから 9 通りの実効エネルギーを測定した が，すべてにおいて管電圧の上昇につれ，実効エネル ギーは直線的な上昇を示した。

\section{2-2 GD-302M のエネルギー依存性と校正定数}

秋田県成人病医療センター, 虎の門病院, NTT 東 日本関東病院の装置において, 同一幾何学的条件で電 離箱線量計と GD-302M にX 線照し，200 $\mu \mathrm{C} / \mathrm{kg}$ で正
規化したエネルギー依存性を Fig. 5 に示す。各装置と も実効エネルギーが上昇すると GD-302M の感度は少 し低下する傾向にあった，特に，AlluraとArtisには 挿入される付加フィルタが多数存在したが, 実効エネ ルギーにおける感度差は少なかった。最小 2 乗法によ り実効エネルギーと GD-302M の感度はInfinix では $y=-0.305 x+35.8\left(R^{2}=0.976, P<0.01\right)$, Allura 全体 では $y=-0.236 x+31.0\left(R^{2}=0.895, P<0.01\right)$, Artis では $y=-0.218 x+31.5\left(R^{2}=0.855, P<0.01\right)$ となった. 3 装置全体では $y=-0.216 x+31.0\left(R^{2}=0.764\right.$, $P<0.01)$ となった.

実効エネルギーと GD-302M のエネルギー校正定数 との関係を Fig. 6 に示す. GD-302M の実効エネル ギーとエネルギー校正定数は最小 2 乗法より, Infinix では $y=0.0044 x+0.113\left(R^{2}=0.971, P<0.01\right)$, Allura では $y=0.0044 x+0.136\left(R^{2}=0.887, P<0.01\right)$, Artis で は $y=0.0039 x+0.138\left(R^{2}=0.853, P<0.01\right)$ となった。 

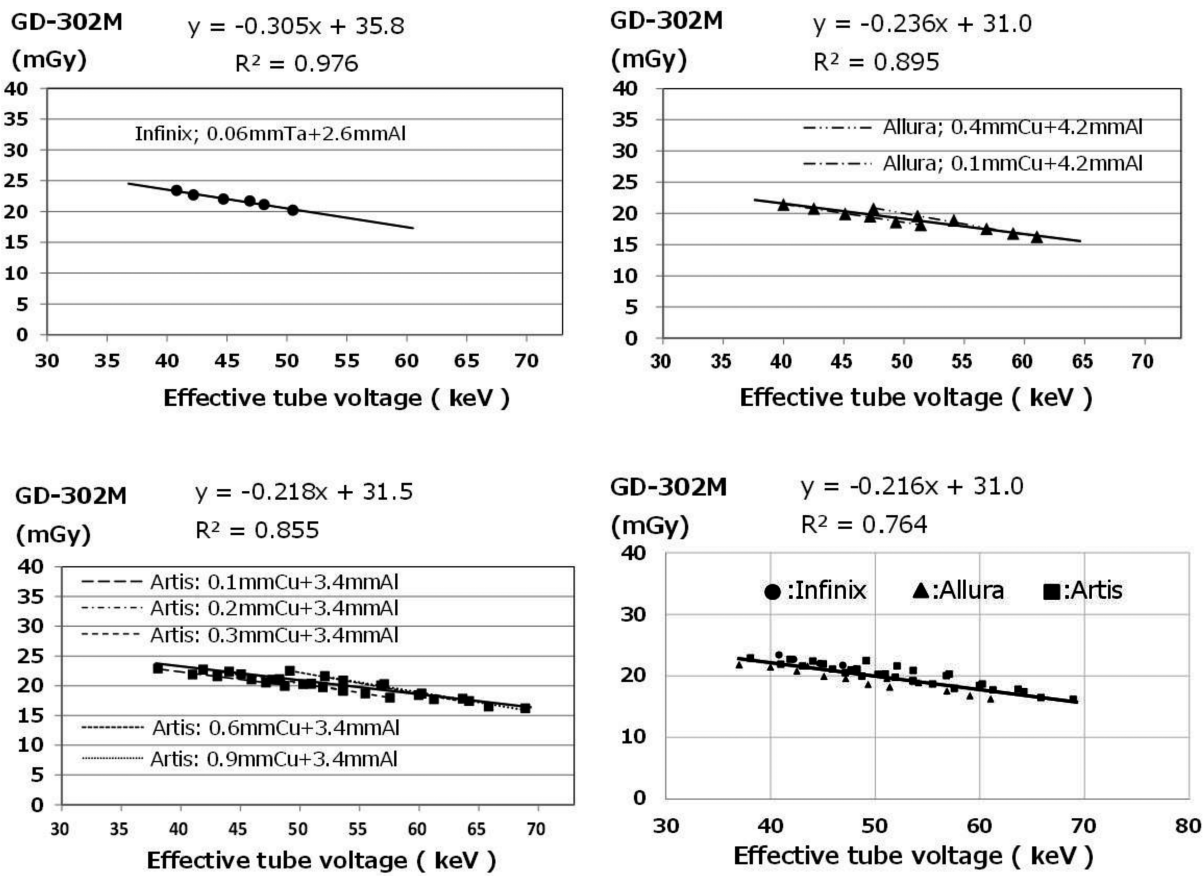

Fig. 5 Effective tube voltage dependence.
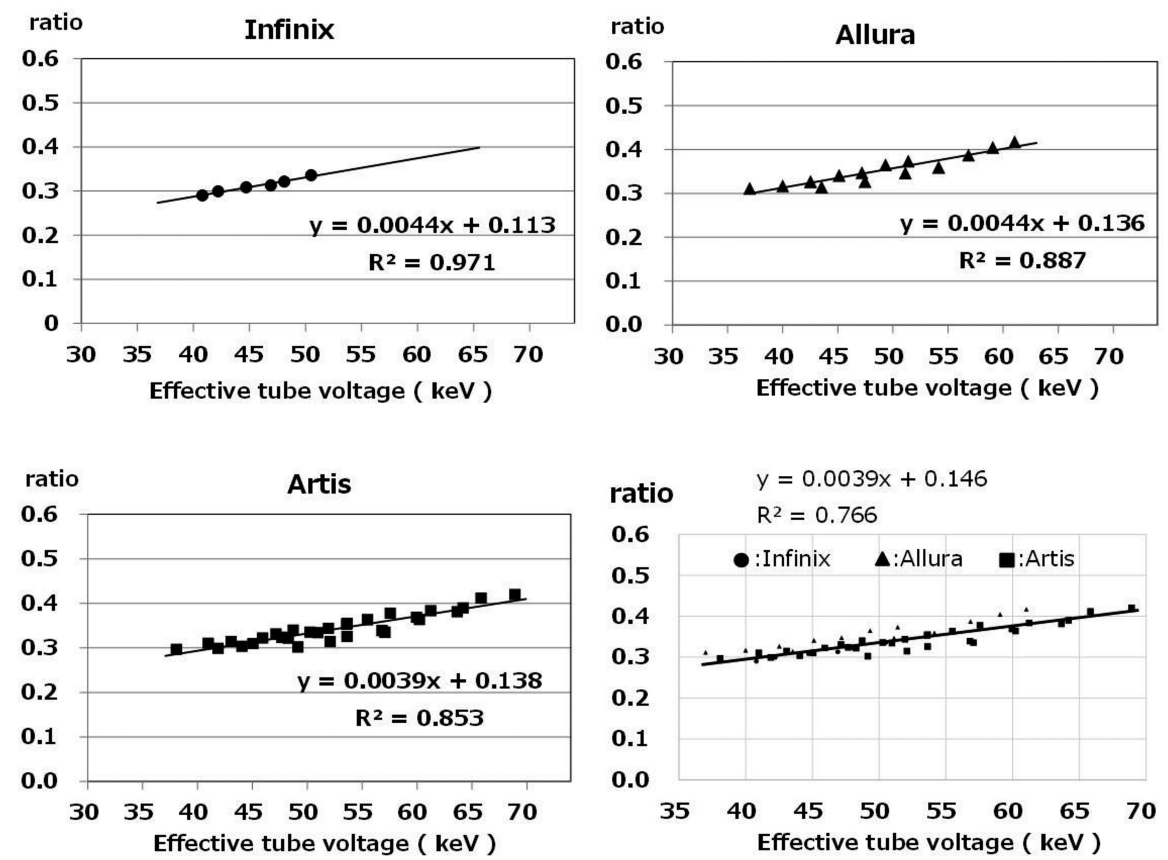

Fig. 6 Calibration factor of the GD-302M.

3 装置全体では $y=0.0039 x+0.146\left(R^{2}=0.766\right.$, $P<0.01)$ となった.

そこで，臨床の使用管電圧の $70 \mathrm{kV}$ から $120 \mathrm{kV}$ ま での校正定数の平均值を求めたところ, 各施設の校正 定数の平均值は秋田県成人病医療センターの Infinix では 0.311，虎の門病院の Allura では 0.356, NTT 東 日本関東病院設の Artis では 0.342 であった。仙台厚 生病院および兵庫医科大学病院は回帰式 $y=$
$0.0039 x+0.146$ から校正定数を推測した結果，その平 均值は 0.363 となった。

\section{2-3 臨床測定}

Fig. 3 に示す胸部 RADIREC ${ }^{\circledR} に$ GD-302M を挿入 し，4 施設で無作為にCAG または PCI 時の皮膚線量 分布㧍よび最大皮膚線量を実測した。

本研究で臨床測定を行った件数は CAG が 19 症例, 
Table 1 Patient characteristics

\begin{tabular}{lcccc}
\hline \hline & $\mathrm{n}$ & Male & Height $(\mathrm{cm})$ & Weight $(\mathrm{kg})$ \\
\hline CAG & 19 & 16 & $159.9 \pm 7.7$ & $60.7 \pm 11.3$ \\
PCI & 43 & 28 & $159.5 \pm 8.2$ & $63.3 \pm 10.7$ \\
\hline
\end{tabular}

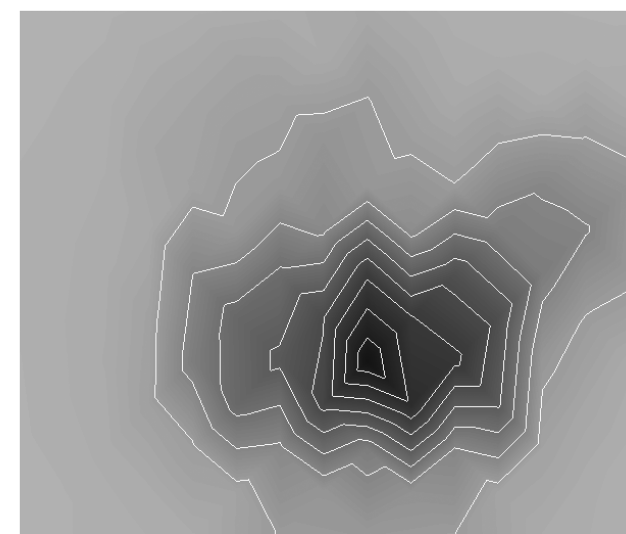

$0.0 \mathrm{~Gy}$

Fig. 7 Dose distribution diagram of the ESD in PCI.

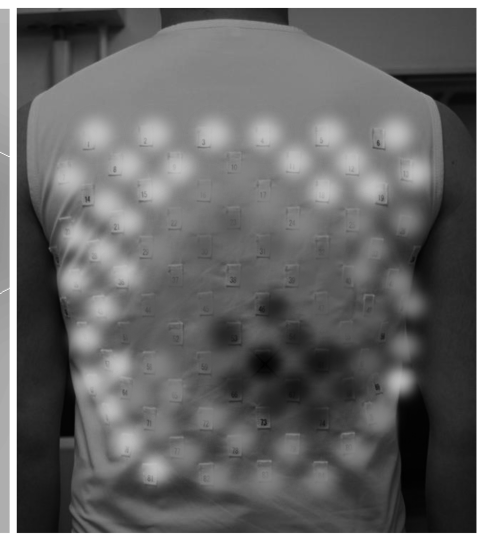

$1.5 \mathrm{~Gy}$

Table 2 Results of dose measurements

\begin{tabular}{lccccc}
\hline \hline & $\mathrm{n}$ & $\mathrm{FT}(\mathrm{min})$ & $\mathrm{DAP}\left(\mathrm{Gy} \cdot \mathrm{cm}^{2}\right)$ & AK $(\mathrm{Gy})$ & MSD (Gy) \\
\hline CAG & 19 & $7.2 \pm 4.8$ & $32.5 \pm 15.3$ & $0.42 \pm 0.14$ & $0.29 \pm 0.16$ \\
PCI & 43 & $24.5 \pm 20.7$ & $82.0 \pm 43.8$ & $1.11 \pm 0.61$ & $1.17 \pm 0.64$ \\
\hline
\end{tabular}

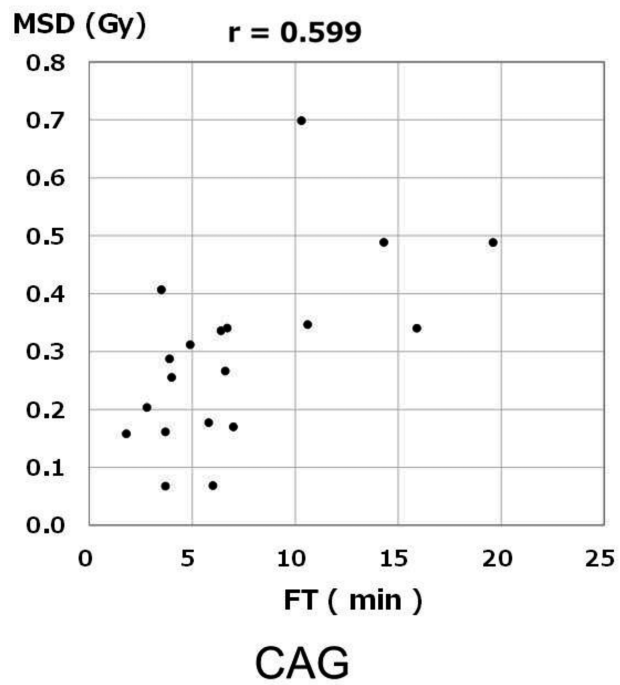

Fig. 8 The correlation between FT and MSD.

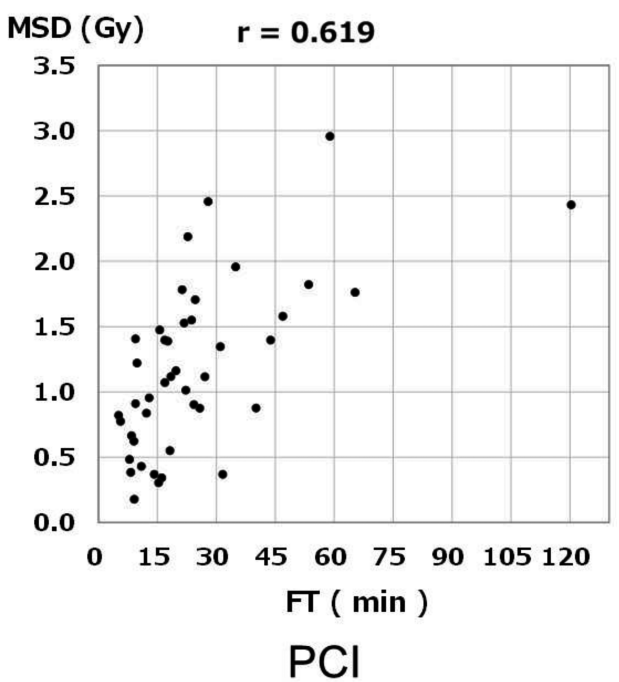

果である。最大皮膚線量は $1.5 \mathrm{~Gy}$ であった。右側に ポケット位置に合わせて皮膚線量をグレー表示したも のを，左側には皮膚線量分布を等高線表示したものを 示す，図より，背部右側の尾側部位が高線領域となっ ていることがわかる。

Table 2 に CAG と PCI におけるFT(min), DAP 


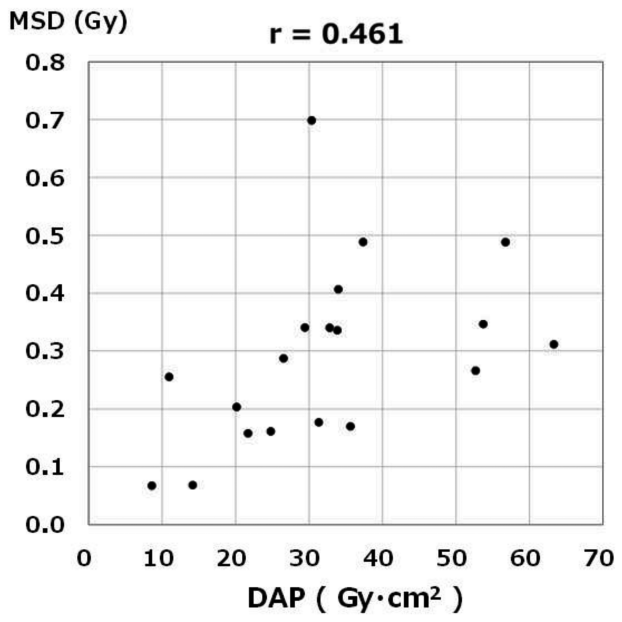

CAG

Fig. 9 The correlation between DAP and MSD

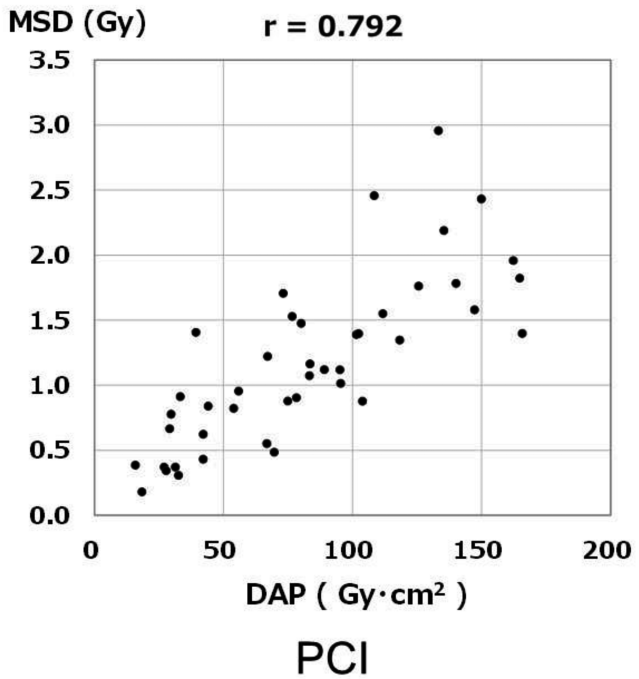

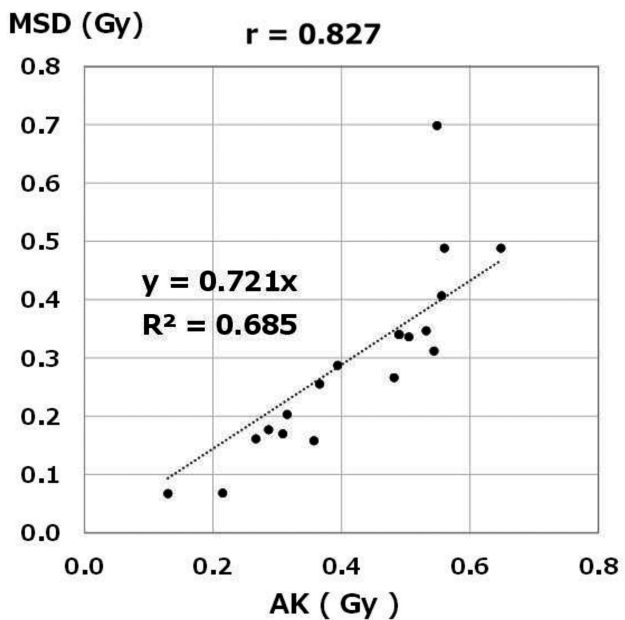

CAG

Fig. 10 The correlation between AK and MSD.

$\left(\mathrm{Gy} \cdot \mathrm{cm}^{2}\right), \mathrm{AK}(\mathrm{Gy}), \mathrm{GD}-302 \mathrm{M}$ で実測した MSD $(\mathrm{Gy})$ の平均值 $\mathrm{S} \mathrm{SD}$ を示す。各パラメータにおいて CAG 群と PCI 群にはすべて有意差 $(P<0.01)$ を認 めた。

MSD と FT, DAP, AK との相関を調べた結果を Fig. 8〜10 に示す.FTと MSD は CAG 群では $r=0.599$, PCI 群では $r=0.619$ と相関を示した。 DAP と MSD は CAG 群では $r=0.461$ と相関を示し, PCI 群では $r=0.792$ と強い相関を示した。AK と MSD は CAG 群では $r=0.827, \quad$ PCI 群では $r=0.887$ と強い相 関を示した。そこで，AK と MSD に対して回帰分析 を行ったところ, CAG 群では $y=0.721 x, R^{2}=0.685$ $(P<0.001), P C I$ 群では $y=1.18 x, R^{2}=0.787$ $(P<0.001)$ となった.

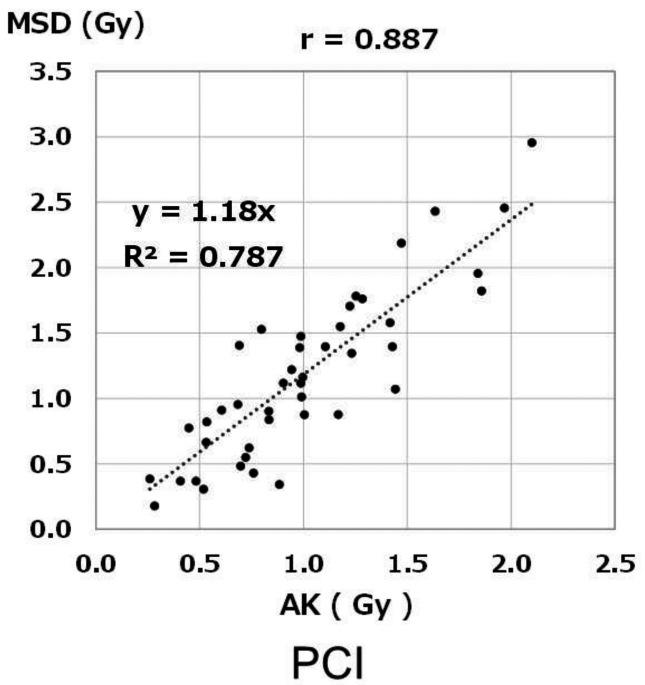

\section{3. 考 察}

Fig. 5 に秋田県成人病医療センター, 虎の門病院, NTT 東日本関東病院に打ける装置の実効エネルギー と GD-302M のエネルギー依存性についての関係を示 した。単一の付加フィルタを使用しているInfinix に 対し, Allura と Artis は複数枚の付加フィルタが装着 され，フィルタの違いにより同管電圧でも実効エネル ギーは異なっていた。しかし，実効エネルギーに対す る GD-302M の感度に大きな差は見られなかった。今 回の 3 装置 8 種類の実効エネルギーと GD-302M の感 度は最小 2 乗法より, 回帰式 $y=-0.216 x+31.0$ が得 られた(Fig. 5)。同様に実効エネルギーとエネルギー 校正定数に対して回帰式 $y=0.0039 x+0.146$ $(r=0.875)$ が得られた (Fig. 6)。この結果から, 装置 
の実効エネルギーを測定することで回帰式から GD$302 \mathrm{M}$ のエネルギー校正定数の推測が可能と考えた. 本研究で使用した胸部 RADIREC ${ }^{\circledR 8)}$ は背面に $2.5 \mathrm{~cm}$ 間隔で GD-302M を 84 個配置しているため, 透視・ 撮影時の照射野の重複も考慮しており，より正確な MSD を評価していると考えられる。また，MSD と FT，DAP，AKの関係を相関分析した結果， CAG と PCI とも AK が MSD と最も強い相関を示した (Fig. 10)。また，回帰分析の結果から AK と MSD は $\mathrm{CAG}$ では $y=0.72 x$ となり, $\mathrm{AK} の$ 值を 0.72 倍, $\mathrm{PCI}$ では $y=1.18 x$ となり, $\mathrm{AK}$ の值を 1.18 倍することで MSD をリアルタイムに推定することが可能であり, 確定的影響である皮膚障害回避に繫がることが示唆さ れた。

Wang10) らは, 患者背部を $3 \times 3$ の 9 領域に分割 し, 各領域に一つの熱ルミネッセンス線量計 (thermoluminescence dosimeter: TLD) を貼付し, CAG と PCI 時の線量分布と最大皮膚線量を測定している. PCI に関して本研究の透視時間の平均值が Wang ら の 1.5 倍にもかかわらず, DAP と AK では本研究の 方が低值であったことは, 臨床線量が低く抑えられて いる可能性が示唆された。逆にMSD が同等の值で あったことは, Wang らの TLD 9 本では測定点が少 ないため MSD を過小評価している可能性も考えら れる。

先般, 医療被曝研究情報ネットワーク(Japan Network for Research and Information on Medical Exposures: J-RIME) が中心となり，日本における DRLs が発表されたＩVRの DRLs は患者照射基準点 に扮ける透視線量率で示された。 以前, 13 学会で構 成される医療放射線防護連絡協議会が出したガイドラ イン11)に準じた線量率表示と推測される。また，この 值は装置の線量管理に使用され，IVRに携わる診療 放射線技師が最も親しみやすく理解しやすい值であ る。しかし，今後は世界的な DRLs と歩調を合わせ る必要性も出て来ると思われる。国際原子力機関 (International Atomic Energy Agency: IAEA)は2010 年に「Patient dose optimization in fluoroscopically guided interventional procedures」を報告した ${ }^{12)}$ 。そ の中で CAG と PCI の DAP データを収集し 75 パー センタイル值を DRLs 構築の参考值として報告して いる，本研究のデー夕が今後の日本の新たな DRLs 構築時の基本データとなるように, 収集した多施設の DAP と AK の 75 パーセンタイル值を Table 3 に示し た。表示にあたって, 本研究の全デー夕と先般発表さ れた本邦の DRLs の中でCTにおいて取り扱った体重
Table 3 75th percentile values of DAP and AK in this study

\begin{tabular}{ccccc}
\hline \hline & & $\mathrm{n}$ & $\begin{array}{c}\mathrm{DAP} \\
\left(\mathrm{Gy} \cdot \mathrm{cm}^{2}\right)\end{array}$ & $\begin{array}{c}\text { AK } \\
(\mathrm{Gy})\end{array}$ \\
\hline CAG & All & 19 & 37 & 0.544 \\
& $50-70 \mathrm{~kg}$ & 13 & 34 & 0.544 \\
PCI & All & 43 & 110 & 1.242 \\
& $50-70 \mathrm{~kg}$ & 29 & 111 & 1.316 \\
\hline
\end{tabular}

$50 \mathrm{~kg}$ から $70 \mathrm{~kg}$ の患者データの両方で比較したが, 差は少なかった。今回収集した症例の体重を Table 1

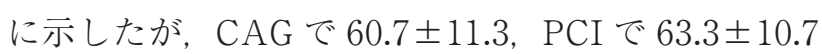
で，50 70 kg の範囲に CAG で 74\%, PCI で $65 \%$ の 症例が入っていたためと思われる。体は欧米に比べ 心臟バイパス手術より PCI の割合が高いことが知ら れている，更に本邦はPCIによる治療率が高く複雑 病変にも適応されるため, 難易度が高いことが知られ ている13)。これら PCIの背景の違いが DAP に影響す ると考えられるため, 患者皮膚線量と直結した指標を 用いて日本の DRL を再構築する必要があると考え る. 本研究では MSD と AK が強い相関を示した、今 後, 確定的影響, 確率的影響を管理する日本の DRLs には AKが取入れられることが望ましいと考える。

\section{4. 結 語}

多施設に扔ける心血管領域のインターベンション時 の皮膚被曝線量を実測した。近年 PCI は難易度の高 い手技が行われるようになってきており, 最大皮膚線 量とその部位を評価することは，放射線障害を回避す ることに繫がると考える。本研究で最大皮虐線量は装 置に表示される AK と強い相関を示した。一次回帰 式より最大皮膚線量は, 積算空気カーマ值を CAGで は 0.72 倍, PCI では 1.18 倍することで推測可能で あった。

本邦の IVRにおける DRLs はアクリル厚 $20 \mathrm{~cm}$ を 用いた患者照射基準点線量率で報告された。これに対 し IAEA では臨床線量であるDAPを用いている。確 定的影響, 確率的影響を管理するには患者皮膚線量を 評価する必要がある。本研究では DAPに比べ AKが 患者皮膚線量を最も反映していることから，AKによ る線量管理の有用性が示された。

\section{謝 辞}

本研究に対しまして御協力を賜りました，秋田県成 人病医療センター, 虎の門病院, 神戸赤十字病院, NTT 東日本関東病院, 仙台厚生病院, 兵庫医科大学 病院のスタッフの皆様に深く感謝申し上げます。 
本研究は公益社団法人日本放射線技術学会 H24, 25 年度学術調査研究班の研究テーマとして行った.
また，本論文の要旨は第 $41 ， 42$ 回日本放射線技術学 会秋季学術大会にて発表した。

\section{参考文献}

1) 日本循環器学会. 2013 年循環器疾患診療実態調査報告 書. http://www.j-circ.or.jp/jittai_chosa/jittai chosa 2013web.pdf (参照 2015. 6. 20)

2) Balter S, Hopewell JW, Miller DL, et al. Fluoroscopically guided interventional procedures: a review of radiation effects on patients' skin and hair. Radiology 2010; 254(2): 326341.

3) Kato M, Chida K, Sato T, et al. The necessity of follow-up for radiation skin injuries in patients after percutaneous coronary interventions: radiation skin injuries will often be overlooked clinically. Acta Radiol 2012; 53(9): 58-61.

4) 奥村恵子, 殿岡永里加，宋 寅傑. IVRにより右肩甲 部に生じた筋層に達する放射線皮膚障害。皮膚病診療 2013; 35(5): 493-496.

5) Kato M, Chida K, Sato T, et al. Evaluating the maximum patient radiation dose in cardiac interventional procedures. Radiat Prot Dosimetry 2011; 143(1): 69-73.

6) Manninen AL, Koivula A, Nieminen MT. The applicability of radiophotoluminescence dosemeter (RPLD) for measuring medical radiation (MR) doses. Radiat Prot Dosimetry 2012; 151(1): 1-9.

7) Kato M, Chida K, Moritake T, et al. Fundamental study on the characteristics of a radiophotoluminescence glass dosemeter with no energy compensation filter for measuring patient entrance doses in cardiac interventional procedures. Radiat Prot Dosimetry 2014; 162(3): 224-229.

8) 加藤 守, 千田浩一, 盛武 敬, 他, 心血管撮影領域 における患者被曝線量測定用装具の開発。日放技学誌 2014; 70(8): 814-820.

9) Seltzer SM, Hubbell JH (前越 久監)。光子減弱係数 データブック．放射線医療技術学叢書 (11)。京都：日 本放射線技術学会, 1995 .

10) Wang W, Zhang M, Zhang Y. Overall measurements of dose to patients in common interventional cardiology procedures. Radiat Prot Dosimetry 2013; 157(3): 348-354.

11）IVRに伴う放射線皮膚障害の防止に関するガイドライ ンおよび測定マニュアルについて。 日放技学誌 2004; 60(8): 1035-1038.

12) International Atomic Energy Agency. Patient dose optimization in fluoroscopically guided interventional procedures. IAEA-TECDOC-1641, 2010.

13）興野寛幸, 一色高明。冠動脈インターベンションの現 状と課題; 日本と世界を比較して. Pharma Medica 2010; 28(4): 9-13. 